\title{
Accessibility and Instructional Technology: Reframing the Discussion
}

\author{
Lloyd P. Rieber, University of Georgia \\ Michele D. Estes, James Madison University
}

\begin{abstract}
Contemporary interpretations of accessibility in education today are largely technology-centered, such as designing and developing alternative representations of text, images, video, and audio resources for people with physical disabilities. However, this interpretation fails to capture the broad value and role of accessibility in its application to design methodologies. When considered across the disciplines of special education, disability studies, and instructional technology, accessibility is a paradigm within which to consider all design activities. Four levels of accessibility are identified along with associated barriers particular to each: social, physical, intellectual, and motivational. This article also reviews the history of design theories of accessibility in education, such as Universal Design for Learning (UDL) and traces its origin to the universal design movement in architecture. Assumptions about what constitutes a disability are also discussed and questioned. Links and commonalities between UDL and instructional design are reviewed suggesting that bridging these design fields using accessibility as an organizing framework offers ways to improve design for all people in society.
\end{abstract}

Keywords: accessibility, Universal Design for Learning, instructional design

The term accessibility is largely interpreted today in education as providing alternative forms of text, images, video, and audio resources to people with varying physical and cognitive disabilities. However, viewing accessibility solely in such a technocentric way is limiting and apt to prematurely stop further considerations of its deeper meanings and interpretations. While it is easy to understand how the scholarship of fields such as special education and disability is pertinent to discussions of accessibility and diversity, the role that instructional technologists play may not be. Yet, instructional technology scholars have also been champions for accessibility diversity in many respects. Instructional technologists are well known for being leaders in the design of learning environments that take full advantage of technological innovations based on what we know about how people learn (cognition) and why (or why not) people want to learn (motivation).

Despite this, the leading scholars of instructional technology have largely ignored the issue of how to provide equal access to learning and education for people with disabilities. In a review ${ }^{1}$ of all 690 articles ever published in Educational Technology Research \& Development through 2013, only six pertained to people with disabilities (i.e. Garcia \& Cuello, 2010; Hertzog \& et al., 1989; Hollins \& Foley, 2013; Mintz \& Aagaard,
2012; Neuman, 1991; Tzeng \& Schwen, 2003). Similarly, although learner analysis is a cornerstone of instructional design theory and practice, the consideration of characteristics of people with disabilities is rarely done. For example, in a review of the seminal instructional design text by Dick, Carey, and Carey (2009), the only mention of accessibility issues or design for people with disabilities is a single paragraph noting the need to "comply with requirements of the American with Disabilities Act" (p. 197) when choosing media. Although one might take the position that analyzing learners' entry skills, prior knowledge of a topic area, and general educational and ability levels subsumes consideration of people with disabilities, this is not a tenable position given the special considerations that such diversity represents and the vast literature from special education and disability studies that is completely missing from instructional design textbooks. To illustrate this gap further, among the 38 chapters in the Reiser and Dempsey (2012) book describing trends and issues in instructional technology, only one chapter (Lewis \& Sullivan,

\footnotetext{
${ }^{1}$ These were the search terms used: Special education; Special needs students; Accessibility (used in the context of disability); Disability; Impairment; Attention Deficit Disorders; Universal design; and Universal design for learning.
} 
2012) deals with diversity and accessibility, with only four pages devoted to people with disabilities.

There is clearly a need for instructional technology scholars to devote more attention to accessibility. The purpose of this paper is to reframe and redefine accessibility more broadly and to show how the work and literature from special education, disability studies, and instructional technology can be linked by the paradigm of accessibility. This offers a new way of understanding the role that instructional technologists play in making education and instruction inclusive for all people while also offering a new framework for instructional design. In this paper, we describe four levels of accessibility that subsumes physical access within a broader framework. We then review some of philosophical and social roots of what it means to be disabled. Attention is then given to probably the most well known instructional design framework related to accessibility, that of Universal Design for Learning. We end by integrating the most contemporary design ideas from the field of instructional technology into an accessibility framework.

\section{Levels of Accessibility}

Accessibility is about having something when you want it or need it and being able to overcome any obstacles that may get in your way when you try to obtain it. Accessibility is about having one's fair share of opportunities, then making the most of those opportunities. Increasing access can be equated with removing or reducing barriers. Defined in this way, accessibility is an issue that affects everyone, not just those with physical and cognitive impairments. The history of design theories of accessibility in fields such as architecture demonstrate that design improves by first examining the needs of people usually viewed at the margins of society (Catanese, 2012). Likewise, designing for accessibility has much promise in informing and improving current instructional design methodologies.

Figure 1. Levels of Accessibility.

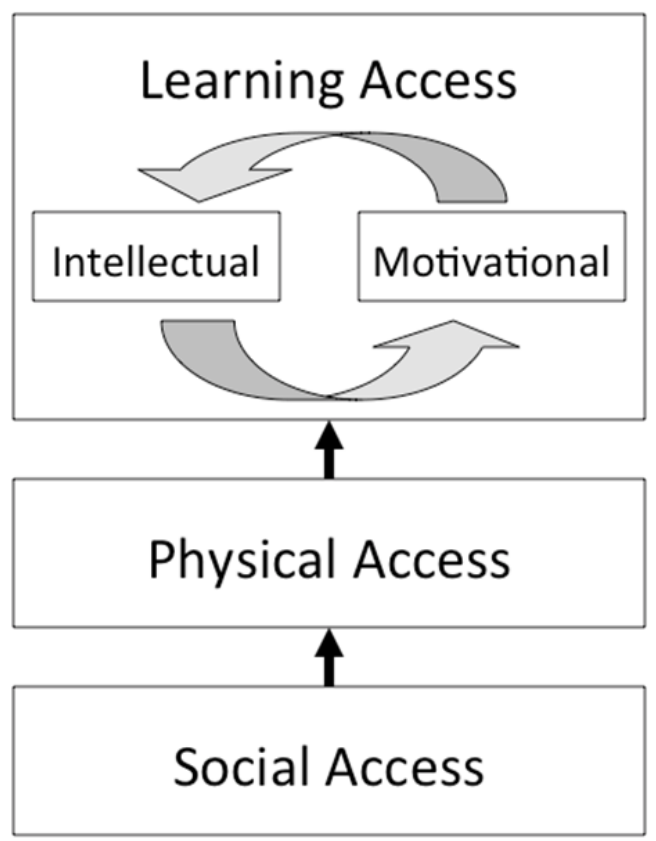

In educational contexts, there are at least four levels of accessibility with associated barriers particular to each (see Figure 1): social, physical, intellectual, and motivational. Each level is prerequisite to the next. The range of accessibility begins with a person's access to information. This type of access is more accurately framed as a social issue, that is, having the opportunity to use resources and materials available to members of a society. The most prevalent obstacle to social access is the financial ability to pay for resources you need. People, who have limited access to basic information and services, whether these are from government, employment, or education, will likewise have much fewer opportunities to reach their full human growth potential. One obviously needs access to a computer and an Internet connection in order to access the information available on the World Wide Web. The difference of access between the most and least privileged in society is often referred to as the Digital Divide (DiBello, 2005; Warschauer \& Matuchniak, 2010). Although instructional technology professionals may be limited in their ability to influence social access for people, opportunities to do so exist, such as the work by David Wiley and his colleagues to advocate for open educational resources demonstrates (Robinson, Fischer, Wiley, \& Hilton III, 2014; Wiley, Green, \& Soares, 2012; Wiley, Hilton, Ellington, \& Hall, 2012).

Physical access addresses cases where the resource is available to an individual, but not in a form that the person can actually use, due to a physical impairment (e.g. sight, hearing). Physical accessibility is the predominate meaning most educators currently attach to accessibility and is the meaning behind such labels as web accessibility standards and being section $508 \mathrm{com}$ pliant. This barrier is largely technical in nature and can be overcome by any design team that chooses to address it. Examples include providing a textual description of a graphic, animation, or video for a person who cannot see in a format compatible with a screen reader that converts the text to spoken speech, or providing a written transcription of the audio track accompanying a video or animation for someone who is unable to hear the audio.

Developers of educational media often resist meeting physical accessibility standards, or do so begrudgingly, often merely to avert lawsuits or to maintain government funding. Indeed, institutions can face significant legal penalties combined with expensive retrofitting of already existing materials if they fail to meet accessibility standards and are challenged in court (Crow, 2008; Edmonds, 2004). However, meeting physical-based accessibility standards is relatively easy and inexpensive for a design team when it is considered from the very beginning of a project, but if it is ignored the design team will need to eventually retrofit the design to make these accommodations. Such retrofitting can be complex, difficult, and expensive.

While physical access is necessary, it is far from sufficient - merely gaining physical access to education, whether the context is a school, training facility, or an online course, is not enough. Learning access is a combination of intellectual access and motivation - a person has both the intellectual capacity to understand the content or skills in the form presented while also desiring to do so. The emphasis on the way the content 
is presented is crucial, otherwise anyone with the needed prerequisite knowledge could learn a subject just by consulting a technical manual. The term form is used here as shorthand for a large number of variables associated with how the content or skill is represented, in what context, and for what purpose. A student who has physical access to a lesson (whether in school or online), but does not understand the concepts being taught based on the strategies chosen by the teacher or designer, is experiencing a problem of accessibility. So too are students who see no relevance of a subject to their lives and choose not to try to learn it - a lack of motivation is a serious obstacle to overcome (Keller, 2008; C. Kim \& Keller, 2010).

Interestingly, the goal of increasing learning access (intellectual and motivational) could be just another way of describing the mission or purpose of the instructional technology field. Educational technology is defined as "...the study and ethical practice of facilitating learning and improving performance by creating, using, and managing appropriate technological processes and resources (AECT Definition and Terminology, 2008, p. 1). The goals of facilitating learning and improving performance imply reducing the intellectual and motivational barriers that learners face by improving the design of learning materials and generating interest and relevance among learners.

Even a casual review of the published research and development by instructional technology scholars demonstrates how the field's major work can be interpreted as increasing learning access to diverse populations. For example, Table 1 presents an informal representative sample of recent research and development work published in the journal Educational Technology Research and Development. Each of these articles has expressed goals of increasing access to learning across a wide range of audiences, topics, and technologies. Most are focused on both intellectual and motivational access. These few examples, though not chosen systematically, demonstrate well the instructional technology

Table 1

Representative sample of the most recent instructional technology research and development published in the journal Educational Technology Research \& Development consistent with an accessibility paradigm.

\begin{tabular}{|c|c|c|c|c|}
\hline Author (Year) & Learning Task/Skill & Technology & $\begin{array}{c}\text { Focus on } \\
\text { Intellectual } \\
\text { Access }\end{array}$ & $\begin{array}{c}\text { Focus on } \\
\text { Motivational } \\
\text { Access }\end{array}$ \\
\hline Baylor (2011) & Improving self-efficacy & Digital agents/avatars & & $\checkmark$ \\
\hline $\begin{array}{l}\text { Huang, Liang, Su, and } \\
\text { Chen (2012) }\end{array}$ & Reading & e-Books & $\checkmark$ & $\checkmark$ \\
\hline $\begin{array}{l}\text { Hwang, Sung, Hung, } \\
\text { Huang, and Tsai (2012) }\end{array}$ & Science & Gaming & $\checkmark$ & $\checkmark$ \\
\hline $\begin{array}{l}\text { Jackson, Brummel, Pollet, } \\
\text { and Greer (2013) }\end{array}$ & Elementary mathematics & Interactive tabletop computers & $\checkmark$ & $\checkmark$ \\
\hline Kang and Zentall (2011) & Geometry & Computer graphics & $\checkmark$ & $\checkmark$ \\
\hline ChanMin Kim (2012) & Remedial mathematics & Virtual change agents & $\checkmark$ & $\checkmark$ \\
\hline Lee and Choi (2011) & Post-secondary education & Online learning & $\checkmark$ & $\checkmark$ \\
\hline $\begin{array}{l}\text { Lim, Song, and Lee } \\
\text { (2012) }\end{array}$ & $\begin{array}{l}\text { Elementary school curricu- } \\
\text { lum }\end{array}$ & Digital textbooks & $\checkmark$ & $\checkmark$ \\
\hline $\begin{array}{l}\text { Liu, Horton, Olmanson, } \\
\text { and Toprac (2011) }\end{array}$ & Middle school science & Problem-based learning & $\checkmark$ & $\checkmark$ \\
\hline $\begin{array}{l}\text { Renninger, Cai, Lewis, } \\
\text { Adams, and Ernst (2011) }\end{array}$ & $\begin{array}{l}\text { Mathematics teacher edu- } \\
\text { cation }\end{array}$ & Online learning & $\checkmark$ & $\checkmark$ \\
\hline $\begin{array}{l}\text { Segedy, Kinnebrew, and } \\
\text { Biswas (2013) }\end{array}$ & Science & Virtual agent & $\checkmark$ & \\
\hline $\begin{array}{l}\text { Shaw, Nihalani, Mayrath, } \\
\text { and Robinson (2012) }\end{array}$ & Reading comprehension & Graphical organizers & $\checkmark$ & \\
\hline $\begin{array}{l}\text { Shelton and Scoresby } \\
\text { (2011) }\end{array}$ & Language arts & Gaming & $\checkmark$ & \\
\hline $\begin{array}{l}\text { Wise, Saghafian, and } \\
\text { Padmanabhan (2012) }\end{array}$ & Educational technology & Online discussions & $\checkmark$ & \\
\hline $\begin{array}{l}\text { Woo, Chu, and Li } \\
\text { (2013) }\end{array}$ & Collaborative writing & Wikis & $\checkmark$ & \\
\hline
\end{tabular}


field's interest in identifying barriers to learning - both intellectual and motivational - and designing creative strategies with existing technologies to reduce or eliminate these barriers. The diversity of people and their learning needs require educational approaches that are likewise diverse in order to accommodate them, as these published articles exemplify.

\section{Considering the Philosophical Roots of Disability}

It is important to stop and reflect on the philosophical roots of the construct of disability. People without a diagnosed disability take it for granted that seeing is better than not seeing, or that hearing is better than not hearing. For example, there is a tendency to "view Western solutions as superior regardless of the systemic implications of those solutions in different cultures" (Carr-Chellman, 2005, p. 8). Likewise, it is easy to assume that it is "better for a child to walk than roll, speak than sign, read print than read Braille, spell independently than use a spell-check, and hang out with nondisabled kids as opposed to other disabled kids" (Hehir, 2002, p. 1). For people without a disability, it is natural that a person without these abilities would be considered not normal. But mixing the terms natural and normal belie a huge set of social constructions that few people recognize. There is currently a debate among scholars of special education and disability whether disability is rooted in biology or sociology referred to, respectively, as the medical model and the social model; see Anastasiou and Kauffman (2011, 2012). As Gallagher, Conner, and Ferri (2014) point out,

In the not too distant past, the meaning of the term disability was thought to be universally self-evident the inability to do something that most others can do as a result of a specific impairment in physical, psychological, or intellectual functioning (p. 1122).

In contrast, those holding a social model view disability as "...something imposed on top of our impairments..." (Union of the Physically Impaired Against Segregation, 1976, p. 3). Impairment is defined as something distinct from disability. Disability is the "result of restrictive social practices imposed upon people with impairments (in sum, a form of oppression)" (Gallagher et al., 2014, p. 1123). Advocates of the social model of disability, similar to many within the field of instructional technology, subscribe to constructivist orientations to learning. That is, what we know is intertwined with our experiences and values.

The label learning disability is applied much more subjectively than would a physical disability. It seems straightforward to state whether or not a person is able to see or hear. However, determining whether such a difference constitutes a disability is far from clear. An interesting historical case study presented by Groce (1985) illustrates this. The case concerns the high percentage of deaf people living in a particular community in Martha's Vineyard in the nineteenth century. These individuals had achieved a higher than average literacy rate due to the number of residents who graduated from the Hartford School, founded by Thomas Gallaudet and later to be known as the American School for the Deaf. It was typical of other people living in the community to have less education - most needed to go and work in the fishing industry at a relatively early age. Consequently, the prevalence of deafness and the distribution of skills among all community members on the island led most hearing people to learn how to sign. Knowing how to sign was considered normal and unremarkable in the community. As this historical example shows, the question of who is disabled in a community is open to multiple interpretations. If the world were dominated by people who did not hear or could not see, the physical infrastructure of society - its buildings, roads, and technologies - would be vastly different, and very likely inconvenient and frustrating for those who happened to have the senses of hearing and sight.

\section{Universal Design for Learning}

Probably the most well articulated perspective on increasing or enhancing accessibility from the special education or disability studies literature is Universal Design for Learning (UDL). We present an overview and brief history of UDL (Rose \& Meyer, 2000, 2002) in order to suggest ways in which it relates or links to contemporary ideas in instructional technology. Interestingly, scholars of special education have called for the UDL philosophy to be considered within an instructional design framework (Basham \& Gardner, 2010; Basham, Israel, Graden, Poth, \& Winston, 2010; Edyburn, 2010). They argue that doing so bridges UDL with the best practices and ideas resulting from the past 30 years of research in instructional technology and the learning sciences.

\section{Historical Background of UDL}

The principles of UDL were developed at the Center for Applied Special Technology (CAST.org). UDL was inspired by, and is a special case of Universal Design, a movement begun in architecture to make physical space accessible to all people regardless of the physical disabilities they might have. Although UDL differs in considerable ways from universal design, it is important to understand the historical connection between the two and the fundamental principles they share. For example, when accessibility is considered at the beginning whether in an architectural or instructional design project - there is no need for expensive and awkward retrofitting in order to accommodate people not served well by the original design. It is useful to first consider the implications of this principle in architecture. For example, consider the need for a person in a wheelchair to enter a large government building built many years ago. It is likely the person will be confronted with dozens of steps leading to huge and heavy front doors. The person would need to be carried up the stairs. The person would need to be helped again to open and pass through the doors. Buildings such as these that were later retrofitted with a wheelchair ramp often required the ramp to be in the back of the building due to space limitations. Having to be carried up steps, or having to enter at the back of the building is a humiliating experience. It makes clear you were not important enough to be considered in the building's original design. You are someone who was not meant to be here.

The term universal design has been best defined by the late Dr. Ron Mace who coined the term while a professor of architecture at North Carolina State University: the "...design of products and environments to be 
usable by all people, to the greatest extent possible, without the need for adaptation or specialized design" (Mace, Hardie \& Place, 1991/1996, p. 2). A core value shared by Universal Design and UDL is that there are primary and secondary audiences who benefit from proactive, inclusive designs. Not only does a person in a wheelchair benefit from the convenience of a universally designed building with an elevator and ramp but so does a delivery person wheeling packages into the building on a dolly, a teenager on crutches who is unable to climb stairs, and a child who finds the ramp preferable to the stairs. Similarly, an educational video that is closed-captioned is of benefit to those with a hearing impairment as well as those in a noisy student center, café, or in the quiet of home when others are asleep and turning the volume up may not be desirable.

As a result of these efforts begun in architecture, the concept of universal design spread to many other areas of public and private life, from environmental initiatives, recreation, and the arts, to health care and now to education.

\section{Research on Universal Design for Learning}

Rose, Harbour, Johnston, Daley, \& Abarbanell (2006) describe the influence of brain research on universal design for learning principles. In their article titled, Universal Design for Learning in Postsecondary Education: Reflections on Principles and their Application, the authors identify recognition, strategic and affective interdependent cognitive networks used during the learning process. Recognition networks work to help an individual sense, recognize, and interpret information in order to assign meaning to patterns from the stimuli being received. Strategic networks help the individual to plan, execute, and monitor actions and skills appropriately based on recognized information. Affective networks lead to engagement and the formation of emotional connections to our perceptions of the world. Table 2 lists the three design principles of UDL, each based on one of the three cognitive networks (CAST, 2011).

Universal Design for Learning and the field of instructional technology have commonalities beyond the use of technology to facilitate meaningful learning experiences. For example, both are grounded in theories of cognitive psychology. According to the National Center on Universal Design for Learning (n. d.):

[UDL] is deeply rooted in concepts such as the Zone of Proximal Development, scaffolding, mentors, and modeling, as well as the foundational works of Piaget; Vygotsky; Bruner, Ross, and Wood; and Bloom, who espoused similar principles for understanding individual differences and the pedagogies required for addressing them (para. 2).

The research and practice of UDL involves leveraging technology to make information accessible and meaningful at a cognitive level for a specified target audience as well as a broader, secondary audience. Principles of UDL call for multiple means of representation to support recognition learning networks, multiple means of action and expression to address strategic thinking, and multiple means of engagement to support learner affect. If an educational intervention supports the recognition, strategic and affective neural networks in this way, it has met the spirit of UDL. Supporting diversity by designing for individuals with special needs at the onset of a project is more efficient and cost effective than retrofitting the technology later. Even so, operationalizing UDL in practice is no easy task. UDL applications often incorporate several layers like Marino's (2009) science intervention where a student could:

...click on the term, hear its definition, and see a visual representation of how the Kelvin scale compares to the Celsius scale (p. 89) [or] ... select the concept and receive a tutorial that included visual representations, animations, supplemental text, and question prompts ( $\mathrm{p}$. 98).

The degree to which each student is served in education depends largely on the attention designers dedicate to meeting individual needs. Such efforts may help narrow the achievement gap that persists among students in the majority and in the minority today (Edyburn, 2010).

Many learners are capable of comprehending content if it is presented in a way that is both accessible and meaningful. Offering multiple representations can serve a variety of learning styles (Spector, 2012). By representing focused content in multiple ways and allowing learners multiple ways to act and express knowledge,

Table 2

Principles of Universal Design for Learning (CAST, 2011)

Principle 1: Provide Multiple Means of Representation

- “Guideline 1: Provide options for perception" (p. 14)

- "Guideline 2: Provide options for language, mathematical expressions and symbols" (p. 16)

- "Guideline 3: Provide options for comprehension" (p. 18)

Principle 2: Provide Multiple Means of Action and Expression

- “Guideline 4: Provide options for physical action" (p. 22)

- "Guideline 5: Provide options for expression and communication" (p. 23)

- "Guideline 6: Provide options for executive functions" (p. 25)

Principle 3: Provide Multiple Means of Engagement

- "Guideline 7: Provide options for recruiting interest" (p. 28)

- "Guideline 8: Provide options for sustaining effort and persistence" (p. 30)

- "Guideline 9: Provide options for selfregulation" (p. 32) 
UDL promises to develop recognition skills and strategic thinking. Consider the UDL Editions by CAST project, where digital online books are designed for readers aged 10 and older. Readers choose maximum, moderate or minimal supports. They explore the meaning and translation of words; add and remove text highlights and compile highlights in a separate window; and follow a four-step process to read strategically. The learner has some control over the presentation of information while interacting with the content that is represented in a number of ways designed to support a range of ability.

UDL is particularly well suited for research and development in the field of instructional technology and in the learning sciences because it represents "a fundamental shift...from external organization of content to one built around the internal workings of the learner" (Center for Applied Special Technology, 2007, p. 2). Research involving instructional design, cognitive tools, and adaptive systems can inform UDL studies that tend to overlook the research and models in the instructional technology field (Marino, 2009). Likewise, instructional technology and the learning sciences may benefit from a UDL approach that serves both primary and secondary target audiences efficiently and to the greatest extent possible. With UDL, those in the margins are placed at the center of design decisions.

\section{Designing for Accessibility}

The first step for practicing accessibility design is the simplest, but perhaps the most important: begin by making a commitment to do so on every instructional project you begin. The second step is to assume diversity is the norm and plan the design to meet both physical accessibility standards and learning accessibility standards. Adopt an attitude that every project should be usable by all learners to the greatest extent. Finally, begin all design efforts from the perspective of persons who are underrepresented or with special needs, including those who may become disadvantaged as a result of poor design.

Part of the design conversations should also acknowledge ways in which other people will benefit from these design accommodations. For example, a design project that will contain animations of important principles, such as the physical relationship between acceleration and velocity, should include narrative explaining the animation from the point of view of someone who cannot see the animation. Rather than consider the writing of such a narrative as a nuisance, the design team should see the task as an opportunity to give a valuable extra resource to those students who can see the animation. Early research on animation from the 1990s demonstrated that students often failed to see the important relationships depicted in the animation. That is, they watched the animation, but they often failed to recognize the principles demonstrated by the animation (Rieber, 1989, 1991). These students would benefit from having these important principles deliberately and carefully pointed out and explained with text or audio (Mayer \& Anderson, 1992a).

A good example of how providing a verbal description benefits everyone is the New York Beyond Site project (http://www.nybeyondsight.org/) where prominent New Yorkers describe their favorite places and landmarks in the city, such as the Brooklyn Bridge and the Apollo Theater. Not only does this make New York's visual culture available to those with visual impairments, but also it also greatly enhances the experience for people who can see. As described on the Web site, a verbal description is "a way of using words to represent the visual world. It helps people who are blind or visually impaired to form mental images of what they cannot see, and provides a new perspective for people with sight" (para. 2).

Meeting the standards for physical access to educational materials, such as designers in the United States complying with Section 508 of the Rehabilitation Act, is a fairly straightforward technical endeavor. Far more difficult, but much more interesting from a design perspective, is how to meet the standards of learning access. Although UDL has been described as an instructional design framework (Basham \& Gardner, 2010; Basham, Meyer, \& Perry, 2010) and instructional design has been described as the essence of Universal Design for Learning (Edyburn, 2010), literature in each area often fails to cite research and practice documented in the other. This may be due to a limited amount of instructional design research and development with attention to diverse learner needs. According to Basham, Israel, et al. (2010) "there is a lack of literature... that considers the merit of...variables such as purposeful instructional design and technology to support all learners" (p. 244). More research in this area is needed.

Edyburn (2010) proposes the following steps for moving forward: (a) design "diversity blueprints" (p. 36) that show how to design interventions for the special needs of learners; (b) focus on product development in order to enable teachers to differentiate in other ways; (c) distinguish what is and is not UDL implementation and assume technology is a critical component; (d) challenge designers, through competition or other means, to develop UDL skills that are refined over time; (e) explore the benefits of cognitive prosthesis (i.e. tools or assistive technologies used to enhance a person's performance [Edyburn, 2007]) on scaffolding and augmenting learning in relation to UDL products; and (f) research the efficacy of UDL by measuring impact on the primary audience, benefits for a secondary audience, and influence on learning and performance.

Although the steps that Edyburn (2010) proposes and the principles on which they are based - are discussed in the special education literature predominately in K-12 school contexts, they apply equally to instructional design efforts in business and industry. As a practical example, consider a hypothetical instructional design project to teach a group of accountants about changes in laws about financial privacy and the implications of those laws in their day-to-day work. Among these accountants are likely a few who are well versed or excel in legal matters, a few who are largely ignorant of legal issues, and the remaining majority who are somewhat familiar. Similarly, a few are likely to be very motivated and interested in legal ideas, a few who are adamant in their dislike for legal topics, and again a remaining majority who are ambivalent. Let's also imagine that this group is older than the general public with typical physical limitations of an older group. Several people in the group also self-report that they are visually or hearing impaired. Where should the design 
start? Design that is content-driven will likely work best just for those who already have much expertise or much motivation to learn. The majority will likely force themselves to complete the instruction at a satisfactory level. The rest would likely find the instruction to be worthless. However, if the designers start their work from the point of view of those will little to no knowledge or interest, they will likely find themselves needing to be much more creative and resourceful in how and what they design. Similarly, by designing text-based alternatives to all visuals and animations in the instruction at the start of the project, the designers will be challenged to be more creative in order to build better examples and cases to present. The resulting instructional design will likely appeal to and be understood by a much larger number of the accountants in this target audience. A key step to understanding this hypothetical example is defining which people are most marginalized in a given group or context. Marginalization can occur at any of the four levels of accessibility, not just those with physical disabilities.

The long history of research in instructional technology also seeks to provide learning access to learners, even though it is not framed this way in the literature. The irony is that this literature rarely included special populations within their research traditions. However, researchers have focused their efforts on understanding how people learn given access to the wide range of technological innovations. As a result, the best of these respective literatures provides significant and appropriate guidance on meeting standards of learning access. Time has come to merge the mission and outcomes of research on special needs, disability, and instructional technology.

These research literatures offer different, but complementary approaches. For example, unlike UDL research, the instructional technology literature is based in psychology, not neurology, but the parallels are easy to spot. The literature on multimedia learning (Mayer, 2001, 2005; Mayer \& Anderson, 1992a, 1992b; Rieber, 1990, 1994) and multiple representations (Ainsworth, 1999; Ainsworth, Bibby, \& Wood, 2002; Moreno \& Duran, 2004) are aligned with the recognition principle. The constructivist literature related to project-based approaches to learning has obvious relevance to strategic principle (Blumenfeld et al., 1991). The vast motivational literature, with Keller's ARCS model as a prime example (Keller, 1983, 2008), is relevant to the affective principle.

Describing an adequate comparison between the UDL and instructional technology literatures is outside of the scope of this paper. However, this point can be made well by considering the most recent work of David Merrill, a pioneering researcher, thinker, and practitioner in instructional technology. Merrill reviewed successful models of learning and instruction across the IT/LS literatures and generated a surprisingly short list of principles found common to all. Consequently, Merrill (2002) labeled these as first principles of instruction due to their foundational nature (see Table 3).

What is most compelling is the way that these principles seem to capture the best ideas from a wide range of epistemological positions, from behavioral to con-
Table 3

Merrill's First Pinciples of Instruction

Principle 1: Task-centered approach

"Learning is promoted when learners are engaged in a task-centered approach, which includes demonstration and application of component skills. A taskcentered approach is enhanced when learners undertake a progression of whole tasks.)" (Merrill, Barclay, \& van Schaak, 2008, p. 174)

Principle 2: Activation

"Learning is promoted when relevant previous experience is activated." (Merrill, 2002, p. 46)

Principle 3: Demonstration (Show me)

"Learning is promoted when the instruction demonstrates what is to be learned rather than merely telling information about what is to be

learned." (Merrill, 2002, p. 47)

Principle 4: Application (Let me)

"Learning is promoted when learners are required to use their new knowledge or skill to solve prob-

lems." (Merrill, 2002, p. 49)

Principle 5: Integration

"Learning is promoted when learners are encouraged to integrate (transfer) the new knowledge or skill into their everyday life." (Merrill, 2002, p. 50)

structivist. For example, these principles capture well design models leading to robust tutorials as well as those leading to microworlds, simulations, and games (diSessa, 2000; Rieber, 2003).

\section{Conclusion}

Addressing individual differences in education has been an ongoing problem in need of a creative solution for decades. While there is a genuine concern for the "democratic value of respect for the individual" (Parker \& Russell, 1953, p. 168) in public education, the ways in which we address individual learner needs have not led to sustainable solutions to achievement gaps affecting "students with disabilities, students of color, students of poverty, and English language learners" (Edyburn, 2010, p. 37). Universal Design for Learning holds promise for many reasons, not the least of which is that it leads to flexible instructional designs for people in and out of the majority. More research on the effects of universal design on primary and secondary audiences is needed (Edyburn, 2010).

By considering individuals who are traditionally at the margins of the intended audience of our design work and moving their needs to the front of our design thinking, instructional designs and technology will address a broad need efficiently and effectively. This shift in design philosophy is important because personal values and assumptions tend to influence one's choice of technologies (Eastmond \& Bentley, 2005) and design decisions (Molenbroek \& Bruin, 2006). Unless we recog- 
nize and advocate for the diverse needs of learners we will continue to develop interventions inherently tainted by our own experiences and perspectives.

Instructional designers and other educators can choose to practice accessibility design for many reasons, such as legal, professional, economic, and moral. From a design perspective, a compelling reason is that embracing an accessibility paradigm should lead to better and more creative designs. These designs begin from the point of view of people who have barriers - physical, intellectual, and motivational - to understanding. The best approach will likely be task-centered, such as students working together on an authentic project that all find important and meaningful. The students will need to have different ways of accessing and interpreting resources. As more resources are created and delivered in digital form, the resources will be inherently more flexible in how they deliver information and engage students. The best resources for learning will be highly interactive and experiential, such simulations, games, and microworlds. These activities begin with the simplest examples of the domain, and provide flexible learning paths as students progress through them.

Current statistics suggest yet another reason to support a design approach based on accessibility - you yourself may one day become a beneficiary with an impairment that requires accommodation. In the United States, one person in five has a disability, “...making people with disabilities the largest minority group and the only group that anyone can join at any time: at birth or through an accident, illness, or the aging process." Based on data collected from the National Health Interview Survey in the United States during 1997-2007 involving over 18,000 people aged 50-64 years, people reported increased mobility-related problems as they age, such as grasping small objects, stooping, bending, and reaching overhead. Other data, such as that from the 1990 United States Census, demonstrate the strong relationship between aging and disability. By the time Americans reach the age of 65 , these data show that $70 \%$ will have a disability of some type, with $25 \%$ having a severe disability (McNeil, 1993).

The field of instructional technology has a long history of developing and researching instructional design models to optimize student learning and understanding (Reiser, 2012; Saettler, 2004). These models have been based on the psychology of learning and motivation coupled with the affordances of technology. Time has come to bring the best ideas from the instructional technology field to the design challenge of meeting all levels of accessibility. In 1991, David Jonassen asked whether the field of instructional systems technology (IST) needed a new philosophical paradigm (Jonassen, 1991), namely that of constructivism. We believe accessibility may represent another major design paradigm for instructional technology in the coming years.

\section{Author Note}

Correspondence concerning this article should be addressed to Lloyd Rieber, Department of Career and Information Studies, 850 College Station Road, 203 River's Crossing, The University of Georgia, Athens, Georgia 30602. Contact: 1rieber@uga.edu.

\section{References}

AECT Definition and Terminology, C. (2008). Definition. In A. Januszewski \& M. Molenda (Eds.), Educational technology: A definition with commentary. New York: Lawrence Erlbaum Associates.

Ainsworth, S. (1999). The functions of multiple representations. Computers and Education, 33, 131-152.

Ainsworth, S., Bibby, P., \& Wood, D. (2002). Examining the effects of different multiple representational systems in learning primary mathematics. Journal of the Learning Sciences, 11(1), 25-61.

Anastasiou, D., \& Kauffman, J.M. (2011). A social constructionist approach to disability: implications for special education. Exceptional Children, 77(3), 367384.

Anastasiou, D., \& Kauffman, J.M. (2012). Disability as cultural difference: Implications for special education. Remedial and Special Education, 33(3), 139149.

Basham, J.D., \& Gardner, J. (2010). Measuring universal design for learning. Special Education Technology Practice, 12(2), 15-19.

Basham, J.D., Israel, M., Graden, J., Poth, R., \& Winston, M. (2010). A comprehensive approach to RTI: Embedding universal design for learning and technology. Learning Disability Quarterly, 33, 243-255.

Basham, J.D., Meyer, H., \& Perry, E. (2010). The design and application of the digital backpack. Journal of Research on Technology in Education, 42(4), 339 -359 .

Baylor, A.L. (2011). The design of motivational agents and avatars. Educational Technology Research and Development, 59(2), 291-300.

Blumenfeld, P.C., Soloway, E., Marx, R.W., Krajcik, J.S., Guzdial, M., \& Palinscar, A. (1991). Motivating project-based learning: Sustaining the doing, supporting the learning. Educational Psychologist, 26(3 \& 4), 369-398.

Carr-Chellman, A.A. (2005). Global perspectives on elearning: Rhetoric and reality. Thousand Oaks, CA: Sage Publications, Inc.

CAST (2011). Universal Design for Learning Guidelines version 2.0. Wakefield, MA: CAST. Retrieved from: http://www.udlcenter.org/sites/udlcenter.org/ files/UDL_Guidelines_Version_2.0_(Final)_3.doc

Catanese, L. (2012). Thomas Lamb, Marc Harrison, Richard Hollerith and the Origins of Universal Design. Journal of Design History, 25(2), 206-217. 
Center for Applied Special Technology. (2007). Summary of 2007 national summit on universal design for learning working groups. Retrieved from: http:// www.cast.org/library/bycast/

UDL_Summit_Summary_All_Invitees_11_29_07.p df

Crow, K.L. (2008). The legal environment of accessible postsecondary online learning. Quarterly Review of Distance Education, 9(2), 169-179.

Cytowic, R.E. (1996). The neurological side of neurospychology. Cambridge, MA: MIT Press.

DiBello, L.C. (2005). Are we addressing the digital divide? Issues, access, and real commitment. Childhood Education, 81(4), 239.

Dick, W., Carey, L., \& Carey, J.O. (2009). The systematic design of instruction (7th ed.). Upper Saddle River, NJ: Pearson Education, Inc.

diSessa, A. (2000). Changing minds: Computers, learning, and literacy. Cambridge, MA: The MIT Press.

Eastmond, N., \& Bentley, J.P.H. (2005). Democratic technology advancement for all: Contrasting views of american and international students. Educational Technology Research \& Development, 53(3), 107113.

Edmonds, C.D. (2004). Providing access to students with disabilities in online distance education: Legal and technical concerns for higher education. American Journal of Distance Education, 18(1), 51-62.

Edyburn, D.L. (2010). Would you recognize universal design for learning if you saw it? Ten propositions for new directions for the second decade of UDL. Learning Disability Quarterly, 33, 33-41.

Gallagher, D.J., Conner, D.J., \& Ferri, B.A. (2014). Beyond the far too incessant schism: special education and the social model of disability. International Journal of Inclusive Education 18:11, 1120-1142, DOI: $10.1080 / 13603116.2013 .875599$

Garcia, A.M.D., \& Cuello, R.O. (2010). A model of equitable and sustainable redistribution of knowledge. Educational Technology Research and Development, 58(6), 781-790.

Groce, N.E. (1985). Everyone Here Spoke Sign Language. Boston: Harvard University Press.

Hehir, T. (2002). Eliminating ableism in education. Harvard Educational Review, 72(1), 1-33.

Hertzog, M., \& et al. (1989). Effects of caption modification and instructor intervention on comprehension of a technical film. Educational Technology Research and Development, 37(2), 59-68.

Hollins, N., \& Foley, A.R. (2013). The experiences of students with learning disabilities in a higher education virtual campus. Educational Technology Research and Development, 61(4), 607-624.

Huang, Y.-M., Liang, T.-H., Su, Y.-N., \& Chen, N.-S. (2012). Empowering personalized pearning with an interactive e-book learning system for elementary school students. Educational Technology Research and Development, 60(4), 703-722.
Hwang, G.-J., Sung, H.-Y., Hung, C.-M., Huang, I., \& Tsai, C.-C. (2012). Development of a personalized educational computer game based on students' learning styles. Educational Technology Research and Development, 60(4), 623-638.

Jackson, A.T., Brummel, B.J., Pollet, C.L., \& Greer, D.D. (2013). An evaluation of interactive tabletops in elementary mathematics education. Educational Technology Research and Development, 61(2), 311332.

Jonassen, D. (1991). Objectivism versus constructivism: Do we need a new philosophical paradigm? Educational Technology Research \& Development, 39(3), 5-14.

Kang, H.W., \& Zentall, S.S. (2011). Computergenerated geometry instruction: A preliminary study. Educational Technology Research and Development, 59(6), 783-797.

Keller, J.M. (1983). Motivational design of instruction. In C. M. Reigeluth (Ed.), Instructional-design theories and models: An overview of their current status (pp. 383-434). Hillsdale, NJ: Erlbaum.

Keller, J.M. (2008). First principles of motivation to learn and e-learning. Distance Education, 29(2), 175 -185 .

Kim, C. (2012). The role of affective and motivational factors in designing personalized learning environments. Educational Technology Research and Development, 60(4), 563-584.

Kim, C., \& Keller, J.M. (2010). Motivation, volition and belief change strategies to improve mathematics learning. Journal of Computer Assisted Learning, 26 (5), 407-420.

Lee, Y., \& Choi, J. (2011). A review of online course dropout research: Implications for practice and future research. Educational Technology Research and Development, 59(5), 593-618.

Lewis, J.P., \& Sullivan, S.M. (2012). Diversity and accessibility. In R. A. Reiser \& J. V. Dempsey (Eds.), Trends and issues in instructional design and technology (3rd ed., pp. 348-357). Boston: Pearson Education, Inc.

Lim, C., Song, H.-D., \& Lee, Y. (2012). Improving the usability of the user interface for a digital textbook platform for elementary-school students. Educational Technology Research and Development, 60(1), 159-173.

Liu, M., Horton, L., Olmanson, J., \& Toprac, P. (2011). A study of learning and motivation in a new media enriched environment for middle school science. Educational Technology Research and Development, 59(2), 249-265.

Mace, R. L., Hardie, G. J. \& Place, J. P. (1991/1996). Accessible environments: Toward universal design. In W.E. Preiser, JC. Vischer, \& E.T. White (Eds.), Design Intervention: Toward a More Humane Architecture (pp. 1-49). New York: Van Nostrand Reinhold. Retrieved from: https://www.ncsu.edu/ncsu/ design/cud/pubs_p/docs/ACC\%20Environments.pdf 
Marino, M.T. (2009). Understanding how adolescents with reading difficulties utilize technology-based tools. Exceptionality, 17(2), 88-102.

Mayer, R.E. (2001). Resisting the assault on science: The case for evidence-based reasoning in educational research. Educational Researcher, 30(7), 29-30.

Mayer, R.E. (Ed.). (2005). Handbook of multimedia learning. New York: Cambridge University Press.

Mayer, R.E., \& Anderson, R.B. (1992a). Animations need narrations: An experimental test of a dualcoding hypothesis. Journal of Educational Psychology, 83, 484-490.

Mayer, R.E., \& Anderson, R.B. (1992b). The instructive animation: Helping students build connections between words and pictures in multimedia learning. Journal of Educational Psychology, 84, 444-452.

McNeil, J. M. (1993). Americans with disabilities: 1991 -92: Data from the survey of income and program participation. (DOC Publication No. 70-33). Washington, D. C.: U. S. Government Printing Office.

Merrill, M.D. (2002). First principles of instruction. Educational Technology Research and Development, 50(3), 43-59.

Merrill, M.D., Barclay, M., \& van Schaak, A. (2008). Prescriptive principles for instructional design. In J. M. Spector, M. D. Merrill, J. J. G. van Merriënboer \& M. P. M. P. Driscoll (Eds.), Handbook of research on educational communications and technology (pp. 173-194). New York: Lawrence Erlbaum Associates.

Mintz, J., \& Aagaard, M. (2012). The application of persuasive technology to educational settings. Educational Technology Research and Development, 60 (3), 483-499.

Molenbroek, \& Bruin, d. (2006). Anthropometry of a friendly rest room. Assistive Technology, 18, 196204.

Moreno, R., \& Duran, R. (2004). Do multiple representations need explanations? The role of verbal guidance and individual differences in multimedia mathematics learning. Journal of Educational Psychology, 96(3), 492.

National Center on Universal Design for Learning. (n. d.). Types of evidence supporting UDL. Retrieved from http://www.udlcenter.org/aboutudl/udlevidence

Neuman, D. (1991). Learning disabled students' interactions with commercial courseware: A naturalistic study. Educational Technology, Research and Development, 39(1), 31-49.

Parker, J.C., \& Russell, D.H. (1953). Ways of providing for individual differences. Educational Leadership, 11(168-174).

Reiser, R.A. (2012). A history of instructional design and technology. In R. A. Reiser \& J. V. Dempsey (Eds.), Trends and issues in instructional design and technology (3rd ed., pp. 17-34). Boston: Pearson Education, Inc.

Reiser, R.A., \& Dempsey, J.V. (Eds.). (2012). Trends and issues in instructional design and technology (3rd ed.). Boston: Pearson Education, Inc.

Renninger, K.A., Cai, M., Lewis, M.C., Adams, M.M., \& Ernst, K.L. (2011). Motivation and learning in an online, unmoderated, mathematics workshop for teachers. Educational Technology Research and Development, 59(2), 229-247.

Rieber, L.P. (1989). The effects of computer animated elaboration strategies and practice on factual and application learning in an elementary science lesson. Journal of Educational Computing Research, 5, 431444.

Rieber, L.P. (1990). Animation in computer-based instruction. Educational Technology Research \& Development, 38(1), 77-86.

Rieber, L.P. (1991). Animation, incidental learning, and continuing motivation. Journal of Educational Psychology, 83, 318-328.

Rieber, L.P. (1994). Computers, graphics, and learning. Madison, WI: Brown \& Benchmark.

Rieber, L.P. (2003). Microworlds. In D. Jonassen (Ed.), Handbook of research for educational communications and technology (2nd ed., pp. 583-603). Mahwah, NJ: Lawrence Erlbaum Associates.

Robinson, T.J., Fischer, L., Wiley, D., \& Hilton III, J. (2014). The impact of open textbooks on secondary science learning outcomes. Educational Researcher, 43(7), 341-351.

Rose, D., Harbour, W.S., Johnston, C.S., Daley, S.G., \& Abarbanell, L. (2006). Universal design for learning in postsecondary education: Reflections on principles and their application. Journal of Postsecondary Education and Disability, 19(2), 135-151.

Rose, D., \& Meyer, A. (2000). Universal design for learning. Journal of Special Education Technology, 15(1), 67-70.

Rose, D., \& Meyer, A. (2002). Teaching every student in the digital age: Universal design for learning. Alexandria, VA: Association for Supervision and Curriculum Development.

Saettler, L.P. (2004). The evolution of American educational technology (2nd ed.). Charlotte, NC: Information Age Publishing.

Segedy, J.R., Kinnebrew, J.S., \& Biswas, G. (2013). The effect of contextualized conversational feedback in a complex open-ended learning environment. Educational Technology Research and Development, 61(1), 71-89.

Shaw, S., Nihalani, P., Mayrath, M., \& Robinson, D.H. (2012). Graphic organizers or graphic overviews? Presentation order effects with computer-based text. Educational Technology Research and Development, 60(5), 807-820. 
Shelton, B.E., \& Scoresby, J. (2011). Aligning game activity with educational goals: Following a constrained design approach to instructional computer games. Educational Technology Research and Development, 59(1), 113-138.

Spector, J.M. (2012). Foundations of educational technology: Integrative approaches and interdisciplinary perspectives. New York: Taylor \& Francis.

The Center for Universal Design. (2014). About UD. Retrieved from http://www.ncsu.edu/ncsu/design/ cud/about_ud/about_ud.htm

Tzeng, J.-Y., \& Schwen, T.M. (2003). Mental representation-based task analysis for analyzing value-laden performance. Educational Technology Research and Development, 51(3), 5-21.

Union of the Physically Impaired Against Segregation. (1976). Fundamental principles of disability. London: The Disability Alliance.

Warschauer, M., \& Matuchniak, T. (2010). New technology and digital worlds: Analyzing evidence of equity in access, use, and outcomes. Review of Research in Education, 34, 179-225.

Wiley, D., Green, C., \& Soares, L. (2012). Dramatically bringing down the cost of education with OER: How open education resources unlock the door to free learning. Washington, DC: Center for American Progress.

Wiley, D., Hilton, J.L., III, Ellington, S., \& Hall, T. (2012). A preliminary examination of the cost savings and learning impacts of using open textbooks in middle and high school science classes. International Review of Research in Open and Distance Learning, 13(3), 262-276.

Wise, A.F., Saghafian, M., \& Padmanabhan, P. (2012). Towards more precise design guidance: specifying and testing the functions of assigned student roles in online discussions. Educational Technology Research and Development, 60(1), 55-82.

Woo, M.M., Chu, S.K.W., \& Li, X. (2013). Peerfeedback and revision process in a wiki mediated collaborative writing. Educational Technology Research and Development, 61(2), 279-309. 
20 WWW.JAID.PUB - October 2017 - ISSN: 2160-5289 